CONTEMPORARY BRITISH INDUSTRIAL RELATIONS 
Also by Sid Kessler

CONFLICT AT WORK (with B. Weekes)

Also by Fred Bayliss

BRITISH WAGES COUNCILS 


\section{CONTEMPORARY BRITISH INDUSTRIAL RELATIONS}

\section{Third Edition}

Sid Kessler

and

Fred Bayliss

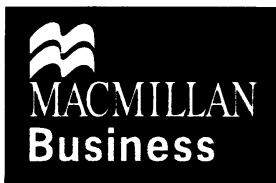


(C) Sid Kessler and Fred Bayliss 1992, 1995, 1998

All rights reserved. No reproduction, copy or transmission of this publication may be made without written permission.

No paragraph of this publication may be reproduced, copied or transmitted save with written permission or in accordance with the provisions of the Copyright, Designs and Patents Act 1988, or under the terms of any licence permitting limited copying issued by the Copyright Licensing Agency, 90 Tottenham Court Road, London W1P 9HE.

Any person who does any unauthorised act in relation to this publication may be liable to criminal prosecution and civil claims for damages.

The authors have asserted their rights to be identified as the authors of this work in accordance with the Copyright, Designs and Patents Acts 1988.

First edition 1992

Reprinted twice

Second edition 1995

Reprinted three times

Third edition 1998

Published by

MACMILLAN PRESS LTD

Houndmills, Basingstoke, Hampshire RG21 2XS

and London

Companies and representatives

throughout the world

ISBN 978-0-333-73187-1 ISBN 978-1-349-14805-9 (eBook)

DOI 10.1007/978-1-349-14805-9

A catalogue record for this book is available from the British Library.

$\begin{array}{llllllllll}10 & 9 & 8 & 7 & 6 & 5 & 4 & 3 & 2 & 1\end{array}$

$\begin{array}{llllllllll}07 & 06 & 05 & 04 & 03 & 02 & 01 & 00 & 99 & 98\end{array}$

Copy-edited and typeset by Povey-Edmondson

Tavistock and Rochdale, England 


\section{Contents}

List of tables ix

List of abbreviations $\quad \mathbf{x}$

List of cases xiii

Acknowledgements $\quad \mathbf{x v}$

Introduction to the third edition $\quad x v i$

1 The early post-war decades, 1945-70 1

Introduction 1

1951-64 3

1964-70 8

$\begin{array}{lr}\text { The Donovan Commission } & 12\end{array}$

The Commission on Industrial Relations $\quad 14$

$\begin{array}{ll}\text { Conclusion } & 16\end{array}$

2 The 1970s 19

Introduction $\quad 19$

$\begin{array}{lr}1970-4 & 20\end{array}$

Incomes policy $\quad 20$

Industrial relations and the law 23

Consequences of the 1971 Act 25

1974-79 27

Incomes policy $\quad 27$

Industrial relations and the law $\quad 29$

Trade unions and employers $\quad 34$

$\begin{array}{ll}\text { Conclusion } & 37\end{array}$

3 The economic background $\quad 38$

$\begin{array}{ll}\text { Introduction } & 38\end{array}$

$\begin{array}{ll}\text { Output and productivity } & 40\end{array}$

Employment and unemployment $\quad 42$

Inflation $\quad 44$

Earnings $\quad 46$

Monetary and fiscal policy $\quad 48$

Balance of payments $\quad 49$

Conclusion $\quad 50$ 
4 Government values and policies $\quad 52$

Introduction $\quad 52$

Full employment $\quad 54$

Inflation $\quad 56$

Public expenditure and the welfare state $\quad 57$

Deregulation $\quad 58$

The role of the individual $\quad 60$

$\begin{array}{ll}\text { Reducing the public sector } & 61\end{array}$

The trade unions $\quad 62$

The employers $\quad 66$

$\begin{array}{lr}\text { Conclusion } & 69\end{array}$

5 The law and industrial relations $\quad 70$

$\begin{array}{ll}\text { Introduction } & 70\end{array}$

Employment Act $1980 \quad 71$

Employment Act $1982 \quad 72$

Trade Union Act $1984 \quad 74$

Wages Act $1986 \quad 75$

Sex Discrimination Act $1986 \quad 76$

Employment Act $1988 \quad 77$

Employment Act $1989 \quad 78$

Employment Act $1990 \quad 80$

Trade Union and Labour Relations (Consolidation) Act $1992 \quad 81$

Trade Union Reform and Employment Rights Act $1993 \quad 81$

Other legislation $\quad 84$

The use of law $\quad 85$

Secondary action $\quad 86$

$\begin{array}{lr}\text { Picketing } & 90\end{array}$

Balloting $\quad 93$

Other legal matters $\quad 95$

The European Union $\quad 99$

Introduction $\quad 99$

$\begin{array}{lr}\text { Equal pay and opportunities } & 100\end{array}$

$\begin{array}{ll}\text { Transfer of undertakings } & 102\end{array}$

$\begin{array}{lr}\text { Collective redundancies } & 103\end{array}$

Working-Time Directive 104

$\begin{array}{ll}\text { European Works Councils } & 105\end{array}$

Medium-Term Social Action Programme 106

$\begin{array}{ll}\text { Social dialogue } & 106\end{array}$

$\begin{array}{lr}\text { Conclusion } & 107\end{array}$

6 Employer and management strategies in the private sector 110

$\begin{array}{ll}\text { Introduction } & 110\end{array}$

Human resource management and management style $\quad 112$

$\begin{array}{ll}\text { Attitudes to unions } & 116\end{array}$

$\begin{array}{ll}\text { Collective bargaining } & 119\end{array}$

Involvement, consultation and participation 123 
$\begin{array}{ll}\text { Flexibility } & 126\end{array}$

Levels and methods of remuneration $\quad 128$

$\begin{array}{ll}\text { Conclusion } & 130\end{array}$

7 Government as employer and quasi-employer $\quad 132$

$\begin{array}{ll}\text { Introduction } & 132\end{array}$

The civil service 134

Local government $\quad 138$

$\begin{array}{ll}\text { Teachers } & 141\end{array}$

The National Health Service $\quad 144$

The nationalised and former nationalised industries $\quad 147$

$\begin{array}{lr}\text { Coal } & 149\end{array}$

Railways $\quad 150$

Steel $\quad 150$

Electricity 152

Gas $\quad 154$

Post Office $\quad 155$

British Telecom 157

$\begin{array}{lr}\text { Conclusion } & 159\end{array}$

8 Trade unions $\quad 162$

$\begin{array}{ll}\text { Introduction } & 162\end{array}$

Trade union membership $\quad 164$

$\begin{array}{ll}\text { Union mergers } & 170\end{array}$

Trade union finances and organisation $\quad 172$

Trade unions and their members 176

$\begin{array}{ll}\text { Trade unions and employers } & 179\end{array}$

$\begin{array}{ll}\text { The Trades Union Congress } & 183\end{array}$

The Trades Union Congress and affiliated unions 189

The Trades Union Congress and government 193

$\begin{array}{ll}\text { Reaction to legislation } & 196\end{array}$

Unions and the Labour Party 199

Unions and the European Union $\quad 200$

$\begin{array}{ll}\text { Conclusion } & 202\end{array}$

9 The institutions of industrial relations $\quad 205$

$\begin{array}{ll}\text { Introduction } & 205\end{array}$

Employers' associations $\quad 207$

$\begin{array}{ll}\text { Collective bargaining } & 209\end{array}$

Recognition and bargaining agents $\quad 209$

$\begin{array}{ll}\text { Bargaining unit level and scope } & 210\end{array}$

$\begin{array}{ll}\text { Productivity bargaining } & 214\end{array}$

$\begin{array}{ll}\text { Third-party intervention } & 215\end{array}$

$\begin{array}{ll}\text { Joint consultation } & 217\end{array}$

$\begin{array}{lr}\text { Conclusion } & 220\end{array}$ 
viii Contents

10 Pay and productivity $\quad 222$

Government objectives and policy $\quad 222$

$\begin{array}{ll}\text { The growth of earnings } & 224\end{array}$

$\begin{array}{ll}\text { The distribution of earnings } & 226\end{array}$

$\begin{array}{ll}\text { Earnings by occupation } & 227\end{array}$

Earnings by industry $\quad 229$

$\begin{array}{ll}\text { Public sector pay } & 230\end{array}$

$\begin{array}{ll}\text { Regional pay } & 233\end{array}$

$\begin{array}{ll}\text { Productivity } & 234\end{array}$

Labour costs per unit of output $\quad 236$

$\begin{array}{ll}\text { Conclusion } & 237\end{array}$

11 Strikes $\quad 239$

Strikes and industrial relations $\quad 239$

$\begin{array}{ll}\text { The strike record } & 242\end{array}$

Comparisons with the strike record in other countries 245

$\begin{array}{ll}\text { Causes of the decline in strike activity } & 247\end{array}$

Changes in the law affecting strikes 250

Strike ballots $\quad 254$

Picketing $\quad 258$

Secondary action $\quad 262$

Conclusion $\quad 263$

12 Assessment and implications for the future 267

$\begin{array}{ll}\text { Introduction } & 267\end{array}$

$\begin{array}{ll}\text { The environment } & 267\end{array}$

$\begin{array}{ll}\text { Trade unions } & 271\end{array}$

$\begin{array}{ll}\text { Employers } & 275\end{array}$

$\begin{array}{ll}\text { Changes in institutions and procedures } & 277\end{array}$

$\begin{array}{ll}\text { Substantive changes } & 279\end{array}$

$\begin{array}{ll}\text { Public sector pay } & 282\end{array}$

Productivity and labour costs $\quad 284$

Changes in the law $\quad 284$

$\begin{array}{ll}\text { Recognition } & 287\end{array}$

$\begin{array}{ll}\text { The closed shop } & 288\end{array}$

$\begin{array}{ll}\text { The check-off } & 289\end{array}$

$\begin{array}{ll}\text { Strikes } & 291\end{array}$

The agenda for collective bargaining $\quad 292$

The European Union $\quad 294$

$\begin{array}{ll}\text { Conclusion } & 295\end{array}$

Appendices $\quad 303$

References $\quad 311$

$\begin{array}{ll}\text { Index } & 320\end{array}$ 


\section{List of tables}

1.1 Union membership and density, 1945-69 (UK) 6

1.2 Industrial disputes, 1945-68 7

2.1 Union membership and density, 1970-9 34

3.1 Output and productivity, 1980-96 (UK) 41

3.2 Gross domestic product 1980-96: international comparisons 42

3.3 Unemployment, 1979-96: international comparisons 43

3.4 Employment, 1979-96 (Great Britain) 45

3.5 Consumer prices, 1980-96: international comparisons 46

3.6 Average earnings, 1979-96: international comparisons 47

7.1 Public sector employment, 1979-96 133

$\begin{array}{lll}7.2 & \text { Privatisation, 1982-97 } & 148\end{array}$

8.1 Trade union membership, 1979-95 165

8.2 TUC membership, 1970-96 167

8.3 Union density of employees, autumn 1996 (Great Britain) 168

8.4 Union density by occupation, autumn 1996 (Great Britain) 169

8.5 Union density by industry,autumn 1996 (Great Britain) 170

8.6 Trade union finance, 1979-95 173

10.1 Average gross weekly earnings, 1979-96 (UK) 225

10.2 Distribution of earnings, 1979-96 (UK) 228

10.3 Average gross weekly earnings, public and private sectors, 1981-96 232

10.4 Regional average gross weekly earnings as proportion of national

10.5 Labour productivity in the business sector, 1960-95 235

10.6 UK unit wage costs, 1980-96 236

11.1 Strikes 1950-96: UK annual averages 243

11.2 Strikes lasting not more than one day, 1970-96: UK annual
averages

11.3 Working days lost by principal cause of strikes, 1970-96 (UK) 245

11.4 Strikes 1980-96 (UK) 246

11.5 Working days lost through strikes per 1000 workers, 1970-95:
international comparisons, all industries 


\section{List of abbreviations}

ACAS Advisory, Conciliation and Arbitration Service

AEU

AEEU

AMMA

APEX

APT\&C

ASLEF

ASTMS

ATL

AUEW

BEC

BIFU

BMA

BPIF

BT

CAB

CAC

CBI

CIR

COHSE

CPSA

CWU

DATA

DE

DTI

EC

EAT

ECJ

ECSC

EEF

EETPU
Amalgamated Engineering Union (previously AUEW)

Amalgamated Engineering and Electrical Union formed by merger of AEU and EETPU

Assistant Masters' and Mistresses' Association

Association of Professional, Executive, Clerical and Computer Staff

Administrative, Professional, Technical and Clerical grades in local government

Association of Locomotive Engineers and Firemen

Association of Scientific, Technical and Managerial Staff

Association of Teachers and Lecturers (formerly AMMA)

Amalgamated Union of Engineering Workers

Building Employers Confederation

Banking, Insurance and Finance Union

British Medical Association

British Printing Industries Federation

British Telecom

Citizens Advice Bureau

Central Arbitration Committee

Confederation of British Industry

Commission on Industrial Relations

Confederation of Health Service Employees

Civil and Public Services Association

Communication Workers Union

Draughtsmen's and Allied Technicians' Association

Department of Employment

Department of Trade and Industry

European Community

Employment Appeal Tribunal

European Court of Justice

European Coal and Steel Community

Engineering Employers' Federation

Electrical, Electronic, Telecommunication and Plumbing Union 


$\begin{array}{ll}\text { EMU } & \text { European Monetary Union } \\ \text { EOC } & \text { Equal Opportunities Commission } \\ \text { EPA } & \text { Employment Protection Act 1975 } \\ \text { ERM } & \text { Exchange Rate Mechanism } \\ \text { ETUC } & \text { European Trade Union Confederation } \\ \text { EU } & \text { European Union } \\ \text { EWC } & \text { European Works Council } \\ \text { FWR } & \text { Fair Wages Resolution } \\ \text { FIET } & \text { International Federation of Commercial, Clerical, Professional and } \\ & \text { Technical Employees } \\ \text { GCHQ } & \text { Government Communications Headquarters } \\ \text { GDP } & \text { Gross Domestic Product } \\ \text { GMB } & \text { General, Municipal and Boilermakers' Union } \\ \text { GNP } & \text { Gross National Product } \\ \text { GPMU } & \text { Graphical Paper and Media Union } \\ \text { HRM } & \text { Human Resource Management } \\ \text { ICFTU } & \text { International Confederation of Free Trade Unions } \\ \text { ILO } & \text { International Labour Organisation } \\ \text { IMF } & \text { International Monetary Fund } \\ \text { IMS } & \text { Institute of Manpower Studies } \\ \text { IPCS } & \text { Institution of Professional Civil Servants } \\ \text { IPMS } & \text { Institute of Professionals, Managers and Specialists (formerly IPCS) } \\ \text { IRSF } & \text { Inland Revenue Staff Federation } \\ \text { ITB } & \text { Industrial Training Board } \\ \text { ITWF } & \text { International Transport Workers' Federation } \\ \text { JIC } & \text { Joint Industrial Council } \\ \text { JRC } & \text { Joint Representation Committee } \\ \text { LAs } & \text { Local Authorities } \\ \text { LFS } & \text { Labour Force Survey } \\ \text { MLC } & \text { Meat and Livestock Commission } \\ \text { MSC } & \text { Manpower Services Commission } \\ \text { MSF } & \text { Management Science and Finance Union (formerly ASTMS and } \\ & \text { TASS) } \\ \text { MTFS } & \text { Medium Term Financial Strategy } \\ \text { NALGO } & \text { National and Local Government Officers' Association (now part of } \\ & \text { UNISON) } \\ \text { NAS/UWT } & \text { National Association of Schoolmasters/Union of Women Teachers } \\ \text { NATFHE } & \text { National Association of Teachers in Further and Higher Education } \\ \text { NBPI } & \text { National Board for Prices and Incomes } \\ \text { NCB } & \text { National Coal Board } \\ \text { NCU } & \text { National Communications Union (formerly POEU) } \\ \text { NEDC } & \text { National Economic Development Council } \\ \text { NEDO } & \text { National Economic Development Office } \\ \text { NES } & \text { New Earnings Survey } \\ \text { NGA } & \text { National Graphical Association (now part of GPMU) } \\ \text { NHS } & \text { National Health Service } \\ \text { NIC } & \text { National Incomes Commission } \\ \text { NIRC } & \text { National Industrial Relations Court } \\ & \end{array}$




\begin{tabular}{|c|c|}
\hline NJAC & National Joint Advisory Council to the Ministry of Labour \\
\hline NMW & National Minimum Wage \\
\hline NUBE & National Union of Bank Employees (now BIFU) \\
\hline NUCPS & National Union of Civil and Public Services \\
\hline NUGMW & National Union of General and Municipal Workers (now GMB) \\
\hline NUJ & National Union of Journalists \\
\hline NUM & National Union of Mineworkers \\
\hline NUPE & National Union of Public Employees (now part of UNISON) \\
\hline NUR & National Union of Railwaymen (now part of RMT) \\
\hline NUS & National Union of Seamen (now part of RMT) \\
\hline NUT & National Union of Teachers \\
\hline OECD & Organisation for Economic Cooperation and Development \\
\hline OFTEL & Office of Telecommunications \\
\hline OPEC & Organisation of Petroleum Exporting Countries \\
\hline POA & Prison Officers' Association \\
\hline POEU & Post Office Engineering Union (now NCU) \\
\hline PSBR & Public Sector Borrowing Requirement \\
\hline PSTCH & $\begin{array}{l}\text { Public Services Tax and Commerce Union (previously IRS and } \\
\text { NUCPS). }\end{array}$ \\
\hline PRP & Performance-Related Pay \\
\hline RCN & Royal College of Nursing \\
\hline RMT & National Union of Rail, Maritime and Transport Workers \\
\hline RPI & Retail Prices Index \\
\hline SCPS & Society of Civil and Public Servants (now part of NUCPS) \\
\hline SOGAT & Society of Graphical and Allied Trades 82 \\
\hline STE & Society of Telecom Executives \\
\hline TASS & $\begin{array}{l}\text { Technical, Administrative and Supervisory Staffs of AUEW } \\
\text { (previously DATA) }\end{array}$ \\
\hline TBF & T. Bailey Forman \\
\hline TECs & Training and Enterprise Councils \\
\hline TGWU & Transport and General Workers Union \\
\hline TINALEA & 'This is not a legally enforceable agreement' \\
\hline TUC & Trades Union Congress \\
\hline TULRA & Trade Union and Labour Relations Acts 1974 and 1976 \\
\hline TUPE & Transfer of Undertakings (Protection of Employment) Regulations \\
\hline UCW & Union of Communication Workers \\
\hline UDM & Union of Democratic Workers \\
\hline UMA & Union Membership Agreement \\
\hline USDAW & Union of Shop, Distributive and Allied Workers \\
\hline WIRS & Workplace Industrial Relations Survey \\
\hline
\end{tabular}




\section{List of cases}

Associated British Ports and others $v$. TGWU (1989) IRLR 291

Austin Rover Group Ltd $v$. TGWU (1984) The Times 12 December 94

Barber $v$. Guardian Royal Exchange (1990) IRLR 240 ECJ 101

Barretts \& Baird (Wholesale) Ltd $v$. IPCS \& Duckworth (1987) IRLR $3 \quad 96$

Blackpool and Fylde College $v$. National Association of Teachers in

Further and Higher Education (NATFHE) (1994) IRLB $493 \quad 98$

Bradley $v$. NALGO (1991) IRLR 159

British Rail $v$. NUR (1989) IRLR 345

Con Mech Ltd $v$. AUEW (1973) ICR 620 (No 2) (1974) ICR 332.

Dekker $v$. Strichting Vormings centrum vor Jong Volurassenen (1991) IRLR 27

Dimbleby $v$. NUJ (1984) IRLR 67

Dines and Others $v$. Initial Health Care Services Ltd and Pall Mall Services $\begin{array}{ll}\text { (1994) IRLB } 498 \text { ECJ } & 102\end{array}$

European Commission $v$. the UK (1994) ECJ cases c/382/92 and 383/92 103

Goad $v$. AUEW (1972) ICR 429 (No 2) (1973) ICR 42; (No 3) (1973) ICR 108.

Heatons Transport (St. Helens) Ltd $v$. TGWU (1972) IRLR 25 25

Hertz v. Alidi Marked k/s (1991) IRLR 31 ECJ 101

Kenny $v$. South Manchester College (1993) IRLB $472 \quad 103$

Langston $v$. AUEW (1973) ICR 211 (1974) ICR 180 and 510

London Borough of Wandsworth $v$. National Association of Schoolmasters
and Union of Women Teachers (1993) IRLR 344 CA

London Underground $v$. NUR (1989) IRLR 341

Marshall $v$. Southampton and South-West Hampshire Health Authority (1986) IRLR 140 ECJ 101

Mercury Communications Ltd $v$. Scott-Garner (1984) ICR 74 CA 95

Merkur Island Shipping Corporation $v$. Laughton (1983) IRLR $218 \quad 86$

Messenger Newspapers Group $v$. NGA (1984) IRLR 397

Miles $v$. Wakefield Metropolitan District Council (1987) IRLR 193

Moss v. McLaclan (1985) IRLR 76 92

News Group Newspapers $v$. SOGAT (1986) IRLR 227

P\&O $v$. National Union of Seamen (1988) 90

Palmer v. Associated British Ports (1993) IRLB $474 \quad 82$ 
xiv List of cases

R v. Mansfield Justices ex parte Sharkey (1985) IRLR 496

$\mathrm{R} v$. Secretary of State for Employment ex parte Equal Opportunities

Commission (EOC) and another (1994) IRLB 493

$R v$. Secretary of State for Employment, ex parte Seymour Smith (1997), IDS

Brief 586

Rask and Christensen $v$. Kantineservice (1993) IRLB 464 ECJ

103

Read Road Transport $v$. NUM South Wales Area (1985) IRLR 67

Rookes $v$. Barnard (1964 AC 1129 (HL)

Secretary for State for Employment $v$. ASLEF (1972) ICR 19 CA

Solihull Council $v$. NUT (1985) IRLR 211

Spar $v$. Schmidt (1994) IRLB $497 \quad 102$

Stratford $v$. Lindley (1965) AC269

Suzen $v$. Zenacher (1997) ECJ Case C 13-9 103

Taylor $v$. NUM Derbyshire Area (1985) IRLR $99 \quad 95$

Taylor \& Foulstone $v$. NUM Yorkshire Area (1984) IRLR 445

Thomas $v$. NUM S. Wales Area (1985) IRLR 136

Wilkins \& Others $v$. St. Helens Borough Council (1997) IRLB 638

Wilson $v$. Associated Newspapers Ltd (1993) IRLB 474

Wilusznski $v$. Tower Hamlets Borough Council (1989) IRLR 259

Wolverhampton Express and Star $v$. NGA (1985) IRLR 222 


\section{Acknowledgements}

In bringing our material up-to-date for the third edition of this book we interviewed, as we did for the first and second editions, 40 or so industrial relations practitioners: mainly union general secretaries and personnel directors of major companies. They are all busy and eminent people and we would like to thank them for devoting their time and for answering our questions with great frankness.

When we were first considering and planning the book we received encouragement and constructive comments from Bill McCarthy, George Bain, Bill Daniel and Pat Lowry, to whom we are most grateful. We are also greatly indebted to the late Hugh Clegg, William Brown, Pat Lowry and Ian Kessler for reading our draft manuscript of the first edition in its entirety, and to Roy Lewis for reading the legal chapters. They all made invaluable and helpful suggestions.

We would also like to thank Anne Stewart, secretary of the Department of Human Resource Management and Organisational Behaviour at the City University Business School, for her hard work, efficiency and good humour in undertaking the administrative and secretarial work involved in the preparation of all editions of this book.

Finally, we are both grateful for the support and encouragement of our wives, Irene and Mary.

Sid KesSLER

FRED BAYLISS

The authors and publishers are grateful to the following for permission to reproduce tabular material: The Organisation for Economic Cooperation and Development's Unemployment 1979-97: International Comparisons; and Blackwell Publishers Ltd and the London School of Economics for material in the British Journal of Industrial Relations in 1983. Every effort has been made to contact all the copyright-holders, but if any have been inadvertently omitted the publishers will be pleased to make the necessary arrangement at the earliest opportunity. 


\section{Introduction to the third edition}

Since 1979 British industrial relations have been affected by powerful forces of a kind previously unknown in the post-war period. Compared with the previous decades, the 1980s and 1990s were years of new departures. These were the result of three major influences.

The first was political. During the whole period up to 1997 there were 'radical' Conservative Governments which, by a series of legislative steps, and in other ways, sought to limit the scope of trade union action, set new rules for trade union operations and enhance the role of management.

The second was economic. Unemployment rose to levels previously thought politically intolerable, reaching over 3 million in 1987. There was a subsequent decline to 1.5 million in the short-lived boom of the late $1980 \mathrm{~s}$ before the second great post-war recession which raised unemployment to nearly 3 million in 1992. The slow economic recovery which followed eventually reduced unemployment significantly to 1.5 million in the summer of 1997. In effect, for most of the last two decades there has been high unemployment compared to the full employment of the early post-war decades. The decline in manufacturing industry was a main reason for the high levels of unemployment but there were other significant changes taking place in the labour market. In particular, there was the continued growth of the private service sector and the increase in the proportion of the labour force which was female and part-time. In addition to labour market changes there were profound product market changes as a result of growing world competition, deregulation and the effects of new technology.

The third was change in management policies. As a result of product market competition and the swing in bargaining power, the initiative was firmly with management, who sought to achieve far greater cost effectiveness than they had in the past. There was also the growth of human resource management with its individualistic undertones as against collectivism. It is 
against this background that the changes in industrial relations have to be considered.

Moreover, if the changes are to be fully understood, they must also be considered against the background of the traditional system of British industrial relations.

The first edition concentrated on the period from 1979 to 1990; the second edition came up to mid-1994; this edition comes up to mid-1997. There was no break in the continuity of developments between 1991 and 1997 so this edition takes the period 1979 to 1997 as being subject to the same influences throughout. There is one major exception to this continuity and that is the election of a Labour Government in May 1997. It is too early to say how far this political change will affect industrial relations. Nevertheless, we do discuss likely changes at some length. Is it the beginning of a new era or not?

We commence in Chapters 1 and 2 with a description of industrial relations in the early post-war decades. At least until the 1970s industrial relations were conducted against a background of full employment and steady economic growth, even if the latter was eventually seen as inadequate compared with that of our main industrial competitors. The post-war 'consensus' - shattered by Mrs Thatcher - included commitment by all political parties to the maintenance of full employment, the welfare state and a mixed economy: that is to say, an acceptance that the public sector as well as the private sector had a significant role to play. It was also accepted that trade unions had an important and legitimate role in industry and in society as a whole, even if there was a growing belief that the balance of power had swung too strongly in their favour.

In retrospect, industrial relations developments in the early post-war years appear to have been relatively unspectacular. But change was constantly taking place, and above all in the growth in certain industries of the power of the shop floor. However, the 1970s saw dramatic events including the reemergence of major national strikes, the imposition of incomes policies and a determined, but unsuccessful, attempt to change the law. All this took place against an economic background of rapidly rising inflation and a marked slowing down in economic growth which was primarily the consequence of the quadrupling of oil prices by the Organisation of Petroleum Exporting Countries in 1973 and the economic reaction to that event by the leading industrial countries.

If industrial relations developments appeared dramatic in the 1970s, they paled almost into insignificance compared with developments since 1979. We commence our analysis of the period since 1979 with the changing environment. In Chapter 3 we consider the economic background, in Chapter 4 government values and policies, and in Chapter 5 changes in the law, including developments in the European Union. While we do not devote a separate chapter to technological change, we are conscious of its rapid 
development and application; reference is made to its important effects in a number of places in the text.

We then move on to consider the parties themselves. Thus Chapter 6 examines management strategies in the private sector, Chapter 7 examines the role of government as an employer and quasi-employer, while Chapter 8 looks at the trade unions, which have basically been at the receiving end of change and have had to struggle to adapt in adverse circumstances.

Having considered the changing political, economic and legal environment and the changes in employers and unions, we move on to examine the effects of these changes and their implications for the conduct of industrial relations in the future. Thus in Chapter 9 we consider the institutions of industrial relations, in Chapter 10 pay and productivity and in Chapter 11 strikes. Finally, in Chapter 12 we make an assessment of the changes which have taken place and their causes, and we look forward to what are likely to be the developments in future. This is the chapter which differs most from the first two editions.

An important part of the preparation of the first two editions was the holding of semi-structured interviews on a confidential basis with over 40 key industrial relations practitioners; for this third edition we have again conducted a similar series of interviews. Our interviewees again consisted on the trade union side of general secretaries and senior officials of most of the major unions and the Trades Union Congress. On the employers' side they included personnel directors of leading companies in both the manufacturing and services sectors, the public sector, former public corporations, and major employers' associations, including the Confederation of British Industries. We would in no way claim that this was a scientific sample, but we do believe that we have interviewed most of the key participants.

Our interviews were based on three simple, but major questions. What has happened since 1979? Why did it happen? What are the implications for the future? The answers to these questions are woven into our assessment. The differences of judgement and emphasis in the responses are brought out as well as the areas of agreement. The book is a combination of academic description and analysis with the reporting of the opinions of those who have shaped the years since 1979 and will be in the driving seat for some years to come. 
To the memory of Allen Flanders 